\title{
Aggregation characteristics of three species of Coccinellidae (Coleoptera) at hibernation sites
}

\author{
Alois HONĚK ${ }^{1}$, ZdeŇKa MARTINKOVÁ ${ }^{1}$ and Stano PEKÁR ${ }^{2}$ \\ ${ }^{1}$ Research Institute of Crop Production, Drnovská 507, CZ 16106 Praha 6 - Ruzyně, Czech Republic; e-mail: honek@vurv.cz \\ ${ }^{2}$ Institute of Botany and Zoology, Masaryk University, Kotlářská 2, CZ 61137 Brno, Czech Republic
}

Key words. Coleoptera, Coccinellidae, Coccinella septempunctata, Ceratomegilla undecimnotata, Hippodamia variegata, overwintering, distribution, hibernaculum

\begin{abstract}
Adults of some coccinellid species overwinter in aggregations consisting of many individuals. They may clump because adults are attracted to particular environmental stimuli and/or of an innate tendency to join conspecific individuals. Aggregation behaviour was studied in Coccinella septempunctata L., which forms small clumps, and Ceratomegilla undecimnotata (Schneider) and Hippodamia variegata (Goeze), which form large clumps. Adults were recorded at five hilltop hibernacula (400-1500 m altitude) in central Europe $\left(50-51^{\circ} \mathrm{N}, 14-16^{\circ} \mathrm{E}\right)$ for periods up to 27 years. The hibernacula occur in areas sparsely covered with isolated grass tussocks or completely with stones. Numbers of adults recorded under each of 300-900 stones or among the stems of the grass tussocks were counted every year at each hibernaculum. The degree of aggregation was determined using Taylor's power law. The coccinellid distributions became more aggregated and the size of the aggregations increased as their abundance increased, less in C. septempunctata than in the other two species. Aggregations formed even in the absence of prominent structures, which may attract immigrants, and even when unoccupied stones or tussocks suitable for overwintering were available. Aggregations may be established and their size limited by the strength of the intrinsic preference to join conspecifics. The supposed advantage of aggregated overwintering must be greater than the risk associated with the easy spread of diseases.
\end{abstract}

\section{INTRODUCTION}

In central Europe the life histories of aphidophagous lady-beetles (Coleoptera: Coccinellidae) are similar. Larval development takes place on aphid infested stands of field crops, wild herbs, shrubs or trees, where one generation (in some species and years 2-3 generations) develop in late spring and early summer. Young adults then forage in temporary habitats, where they feed on both insect and vegetable food but do not reproduce. They search for places to overwinter (hibernacula), usually small areas often well delimited against the surroundings, with a typical ground surface structure, vegetation cover and microclimate (Hodek, 1996). Hibernacula may be scattered in the agricultural landscape, along forest margins, in gardens, in dry vegetation in ruderal areas or on walls of buildings. Some individuals of some species fly to prominent hilltops, often several kilometres away from where they bred. At these sites diapausing or quiescent adults stay from mid-summer (July-August) until the following spring (April-May), shelter in various structures and largely refrain from feeding (Hagen, 1962; Hodek, 1996). Thus, they spend a considerable amount of time in hibernation and have physiological and behavioural adaptations that minimize mortality during this period.

Hibernating adults may aggregate in clumps, which usually consist of a few but sometimes tens of thousands of individuals. Aggregations may arise passively, because individuals are attracted to particular structures and/or microclimatic conditions and there are few such struc- tures. However aggregations might originate from an intrinsic tendency to join conspecifics and clump together even when there are many convenient hibernating sites still available. Overwintering in clumps rather than singly may alter the chance of survival. Ecological theory predicts that clumping may decrease the risk of predation and/or parasitism (Sillen-Tullberg \& Leimar, 1988; Turchin \& Kareiva 1989; Mooring \& Hartl, 1992). However, the high population density achieved in clumps may also facilitate the spread of disease (e.g. Bellows \& Hassell, 1999).

Aggregation was studied in three species that differ in their overwintering habits, Coccinella septempunctata L., Ceratomegilla undecimnotata (Schneider) and Hippodamia variegata (Goeze). The hibernation behaviour of C. septempunctata is plastic (Hodek, 1960). The adults of this species move between habitats (Ricci et al., 2005) before flying to hibernacula (Honěk, 1990; Nedvěd et al., 2001). Many individuals hibernate at lowland sites with warm microclimates (southern slopes and woodland margins, roadsides), where they overwinter under dead leaves or various debris, in dry vegetation, singly or in small groups (Honěk, 1989). Adults that fly to hilltop hibernacula overwinter in grass tussocks or under stones, singly or in groups that may consist of several tens of individuals (Honěk, 1989; Ceryngier, 2000). The abundance of overwintering adults varies between years (Honěk \& Martinková, 2005). Ceratomegilla undecimnotata is a thermophilic species which breeds on herbaceous plants in agricultural landscapes. Diapausing and quiescencent adults (Katsoyannos et al., 2005) fly to hilltops 
where they aggregate and may establish very conspicuous overwintering clumps consisting of several thousands of individuals (Hodek, 1960). Unlike both former species, H. variegata can complete 2-3 generations per year and may become very abundant in warm years (Honěk \& Rejmánek, 1982). It overwinters in a variety of lowland and hilltop hibernacula, singly or in small groups, frequently together with one of the other coccinellid species (Hodek, 1960). Aggregations consisting of several tens of individuals were observed at high altitude hibernacula in central and northern Slovakia and smaller clumps on hilltops near the sites used in this study (A. Honěk, unpubl.).

Since 1978, the distribution and abundance of C. septempunctata was studied at five overwintering sites in the west of the Czech Republic. These hibernacula are natural grasslands or rock debris fields, on the southern slopes of hills. All these sites provide many places for overwintering as they are covered by thousands of grass tussocks or stones, all of similar size and quality. The coccinellid aggregations at these hibernacula are apparently formed spontaneously, as there is an abundance of places for hibernation. $C$. undecimnotata and $H$. variegata occurred at only two localities. The objectives of this study were to determine (i) whether the coccinellid distribution is aggregated, (ii) how clump size varied with overall species abundance and (iii) whether aggregation behaviour differs between species.

\section{MATERIAL AND METHODS}

\section{Overwintering sites}

Overwintering adults of $C$. septempunctata, $C$. undecimnotata and $H$. variegata were counted at a hibernation site at Raná hill $\left(50^{\circ} 24^{\prime} \mathrm{N}, 13^{\circ} 46^{\prime} \mathrm{E}\right.$, atitude $390 \mathrm{~m}$ a.s.l.) and Srdov hill $\left(50^{\circ} 24^{\prime} \mathrm{N}, 13^{\circ} 47^{\prime} \mathrm{E}\right.$, altitude $440 \mathrm{~m}$ a.s.l.) in the west of the Czech Republic. Both areas are natural grassland and covered with grass tussocks spaced 5-20 $\mathrm{cm}$ apart on bare ground. They are on southwestern slopes near the tops of the hills. At these sites the soil is shallow $(2-5 \mathrm{~cm})$ and on vulcanic bedrock, and exposed to sun and wind. Hibernacula on Velký Studenec $\left(50^{\circ} 50^{\prime} \mathrm{N}, 14^{\circ} 27^{\prime} \mathrm{E}, 720 \mathrm{~m}\right)$, Obří Hřeben $\left(50^{\circ} 44^{\prime} \mathrm{N}, 15^{\circ} 45^{\prime} \mathrm{E}\right.$, $1420 \mathrm{~m}$,$) and Studničná hora hills \left(50^{\circ} 43^{\prime} \mathrm{N}, 15^{\circ} 42^{\prime} \mathrm{E}, 1480 \mathrm{~m}\right)$ were occupied only by $C$. septempunctata. These hibernacula were in fields of rock debris. At each hibernaculum coccinellids were counted each year within the same plot, the size of which $\left(100\right.$ to $\left.250 \mathrm{~m}^{2}\right)$ differed between hibernacula. At all sites the area suitable for hibernation extended beyond the limits of the plot searched for coccinellids. The Raná hibernation site was checked once each year from 1978 to 2004, the other hibernacula from 1979 to 1988 and from 2002 to 2003.

\section{Coccinellid abundance}

Adults of the three species overwinter deep between the densely packed stems of grass tussocks. In rock debris fields the coccinellids are on the undersides of stones. A standard method of counting was used throughout the study. Every year at each hibernation site coccinellids were counted on one day, between September 20 - October 20. At this time coccinellid immigration had ceased and hibernation mortality was minimal. Numbers of individuals hibernating in each tussock or under each stone were recorded separately. The stems of the grass tussocks were spread apart and the coccinellids counted. On rock debris fields surface stones were turned and the number of coccinellids on the undersides recorded. Every year at each hibernation site
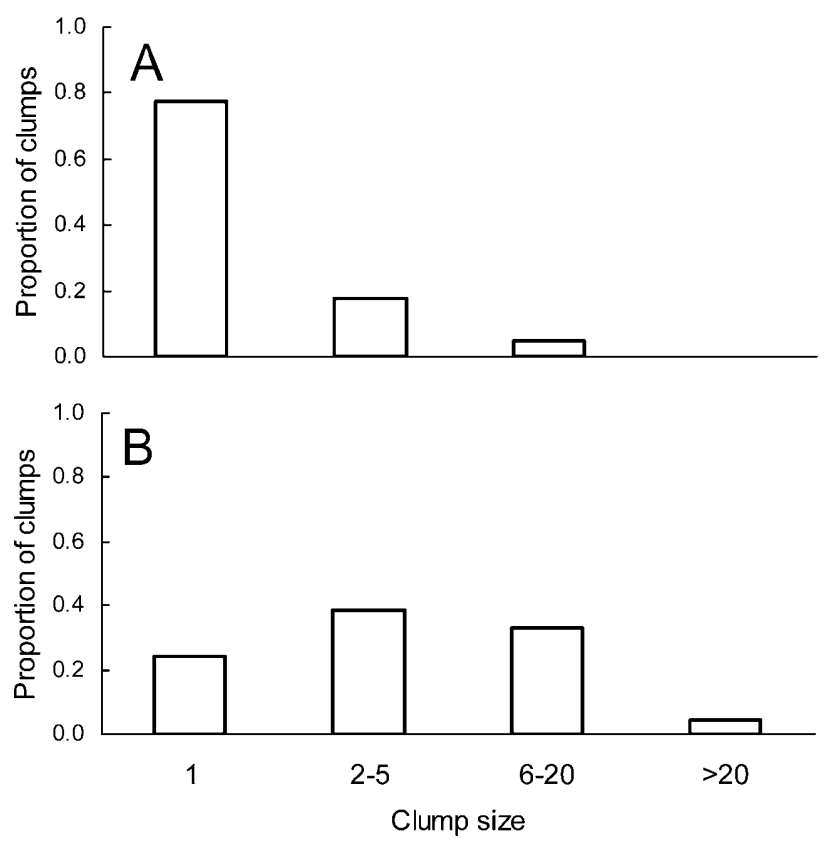

Fig. 1. Distribution of clump sizes in years with contrasting population densities. Data for C. septempunctata, Raná, 1978-2003. Years when there were A - less than 10 individuals per 100 tussocks $(1987-8,1994-5,1997,1999,2001-3$, B more than 100 individuals per 100 tussocks $(1979,1981-2$, 1985-6, 1989, 1992, 1996).

presence of coccinellids was established in $3 \times 100$ to $9 \times 100$ (usually $5 \times 100$ ) tussocks or under a similar number of stones. When several coccinellids occupied one tussock or were present under one stone it was considered to be a "clump" even when they were actually a few centimeters apart. Before the onset of the cold winter period, individuals in such loose groups may frequently change their position, crawl around, bask in the sun but finally form dense clumps (A. Honěk, unpubl.). The total number of individuals recorded was 14,373 C. septempunctata (39,400 tussocks/stones inspected), 714 C. undecimnotata (6,800 tussocks) and 110 H. variegata (6,000 tussocks).

\section{Data processing}

Average number of each species of coccinellid present at a site in a particular year ("abundance") was calculated as the arithmetic mean of the mean number per hundred tussocks/stones. Statistical analyses were performed within R (R Core Development Team, 2004). In order to identify whether the distribution of each coccinellid species was random or clumped Taylor's power law was used (Taylor, 1961), i.e. a regression of variance on mean, both on a logarithmic scale. For a random distribution the slope of the regression line is equal to "1", while for a clumped distribution the slope is greater than " 1 ". Whether the slope parameter differed from unity was tested using a t-test. To determine how the degree of clumping changes with abundance, the index of dispersion (ID), i.e. variance-to-mean ratio (Ludwig \& Reynolds, 1988), was estimated for each sample, which was then regressed on standardised sample sizes, both on logarithmic scales to normalize the distribution of the variables. In both analyses linear models were compared using ANCOVA with species as a factor and sample sizes as a covariate. Minimal adequate model was achieved by combining factor levels (Crawley, 2002). 


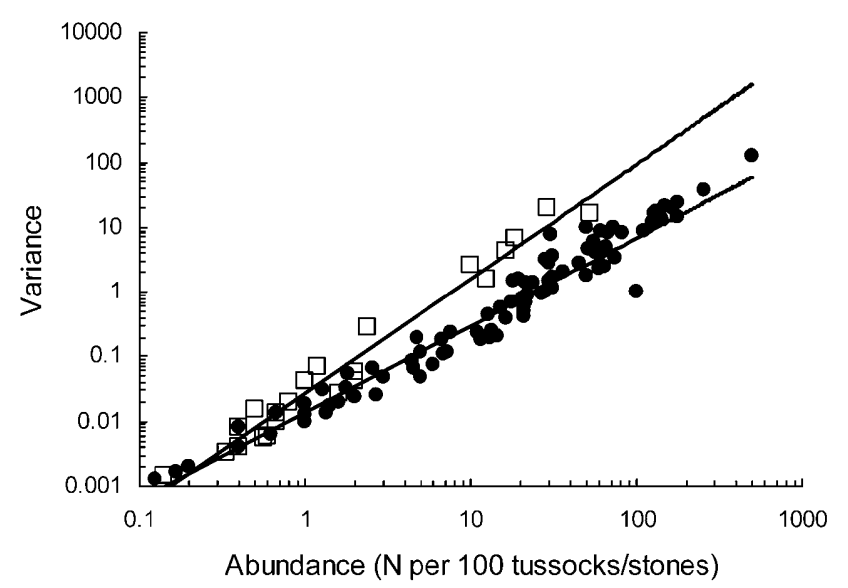

Fig. 2. Variance in clump size plotted against abundance at particular sites for $C$. septempunctata $(\bullet)$ and a combined sample of $H$. variegata and C. undecimnotata $(\square)$. Combined data for all hibernacula and years. Parameters of the individual linear models $(\log [\mathrm{y}]=\log [\mathrm{a}]+\mathrm{b} \log [\mathrm{x}])$ are: C. septempunctata $\mathrm{a}=2.50, \mathrm{~b}=1.38, H$. variegata and C. undecimnotata $\mathrm{a}$ $=7.17, \mathrm{~b}=1.77$.

\section{RESULTS}

\section{Aggregated distribution}

For each species and overwintering site the abundance varied between years. The size of the clumps and the frequency of large clumps increased with overall abundance. This was apparent in C. septempunctata (Fig. 1) as well as in $H$. variegata and C. undecimnotata, for which there was less data. The analysis of variance vs. abundance plots (Taylor's power law) revealed that the regression slopes were significantly greater than "1" suggesting that all three species aggregate (Fig. 2). There was a significant difference between the regression models for the different species (ANCOVA, $\mathrm{F}_{2,107}=9.49, \mathrm{P}=0.0001$ ). Models for $H$. variegata and C. undecimnotata were combined because they were similar in both slope and intercept $\left(\right.$ ANCOVA, $\mathrm{F}_{3,20}=2.1, \mathrm{P}=0.12$ ). The combined

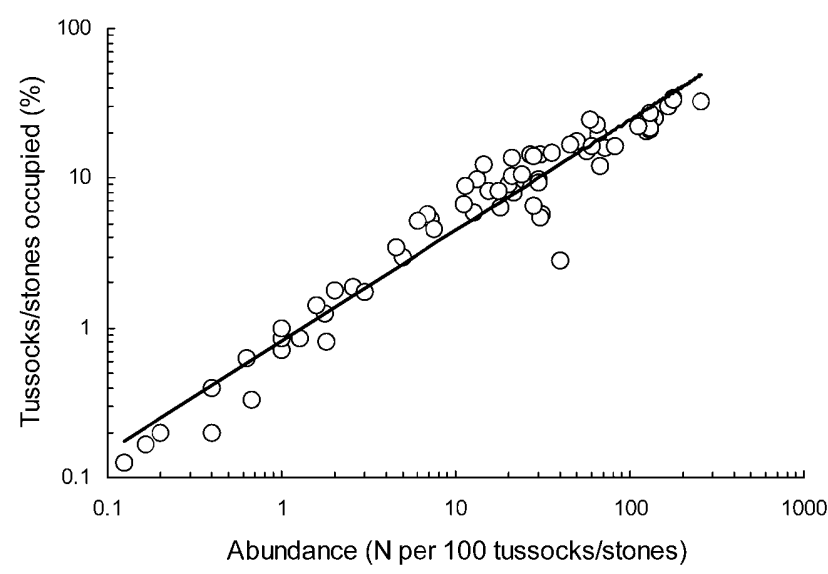

Fig. 3. Percentage of tussocks/stones occupied plotted against average abundance of $C$. septempunctata. Data for all hibernation sites and years. Parameters of the linear model $(\log [\mathrm{y}]=$ $\log [\mathrm{a}]+\mathrm{b} \log [\mathrm{x}]): \mathrm{a}=-0.088, \mathrm{~b}=0.739$.

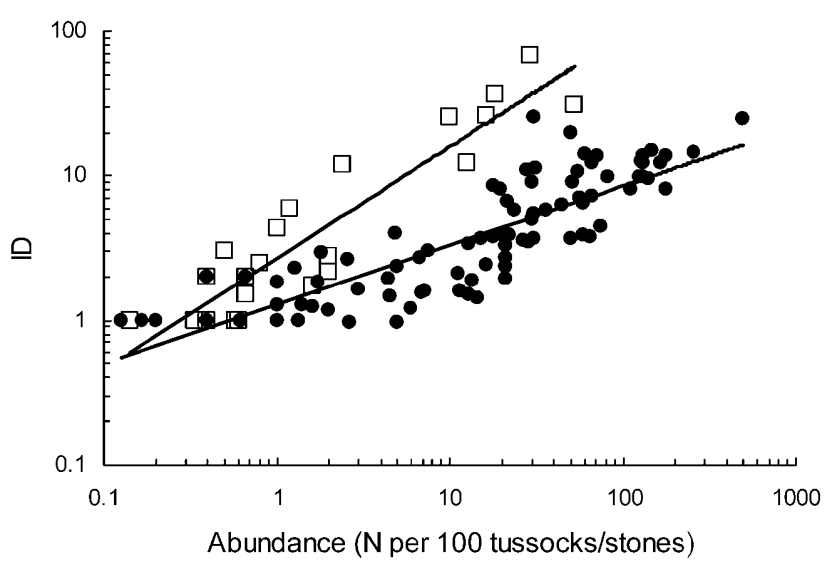

Fig. 4. The index of dispersion (ID) plotted against abundance at particular sites for $C$. septempunctata $(\bullet)$ and a combined sample of $H$. variegata and C. undecimnotata ( $\square$ ). Combined data for all hibernacula and years. Parameters of the individual linear models $(\log [\mathrm{y}]=\log [\mathrm{a}]+\mathrm{b} \log [\mathrm{x}])$ are: C. septempunctata $\mathrm{a}=0.099, \mathrm{~b}=0.417, \mathrm{H}$. variegata and C. undecimnotata $\mathrm{a}=0.431, \mathrm{~b}=0.769$.

model for these two species was significantly different from the model for C. septempunctata, in both parameters (ANCOVA, $\left.\mathrm{F}_{1,109}=25.7, \mathrm{P}<0.0001\right)$. The slope of the regression model for the combined data of $H$. variegata and $C$. undecimnotata (t-test, $\mathrm{P}<0.001$ ) was steeper than that for $C$. septempunctata (t-test, $\mathrm{P}=0.005$ ). This indicates that the former species aggregated more intensely than $C$. septempunctata. The proportion of occupied tussocks/stones increased with abundance but some tussocks/stones were always unoccupied. For C. septempunctata (Fig. 3) the proportion of occupied tussocks/stones increased with abundance $\left(\mathrm{R}^{2}=0.940, \mathrm{P}\right.$ $<0.0001)$ but all were only occupied at abundances of 670 individuals per 100 tussocks/stones.

\section{Group size}

Analysis of the ID vs. mean abundance plots (Fig. 4) revealed species differences in the relationship between abundance and clump size (ANCOVA, $\mathrm{F}_{2,107}=9.5, \mathrm{P}=$ 0.0001 , Fig. 2). Both parameters in the regression models for $H$. variegata and $C$. undecimnotata were similar (ANCOVA, $\mathrm{F}_{3,20}=2.1, \mathrm{P}=0.12$ ). Both parameters of the combined model for both species are significantly different from those of the model for C. septempunctata (ANCOVA, $F_{1,109}=25.7, \mathrm{P}<0.0001$ ). The difference in slope indicated that $H$. variegata and $C$. undecimnotata tend to overwinter in larger clumps (ID $=60$ ) than $C$. septempunctata (ID $=20)$. Because of the greater tendency to aggregate a greater proportion of $C$. undecimnotata than C. septempunctata overwintered in large clumps (Fig. 5).

\section{DISCUSSION}

Some species of coccinellids characteristically aggregate during hibernation. A number of explanations for this behaviour have been proposed (Hodek, 1960), but only a few species have been studied in detail (Hodek, 1996). Massive aggregations of Hippodamia convergens Guerin were studied by Hagen (1962). The adults may be 

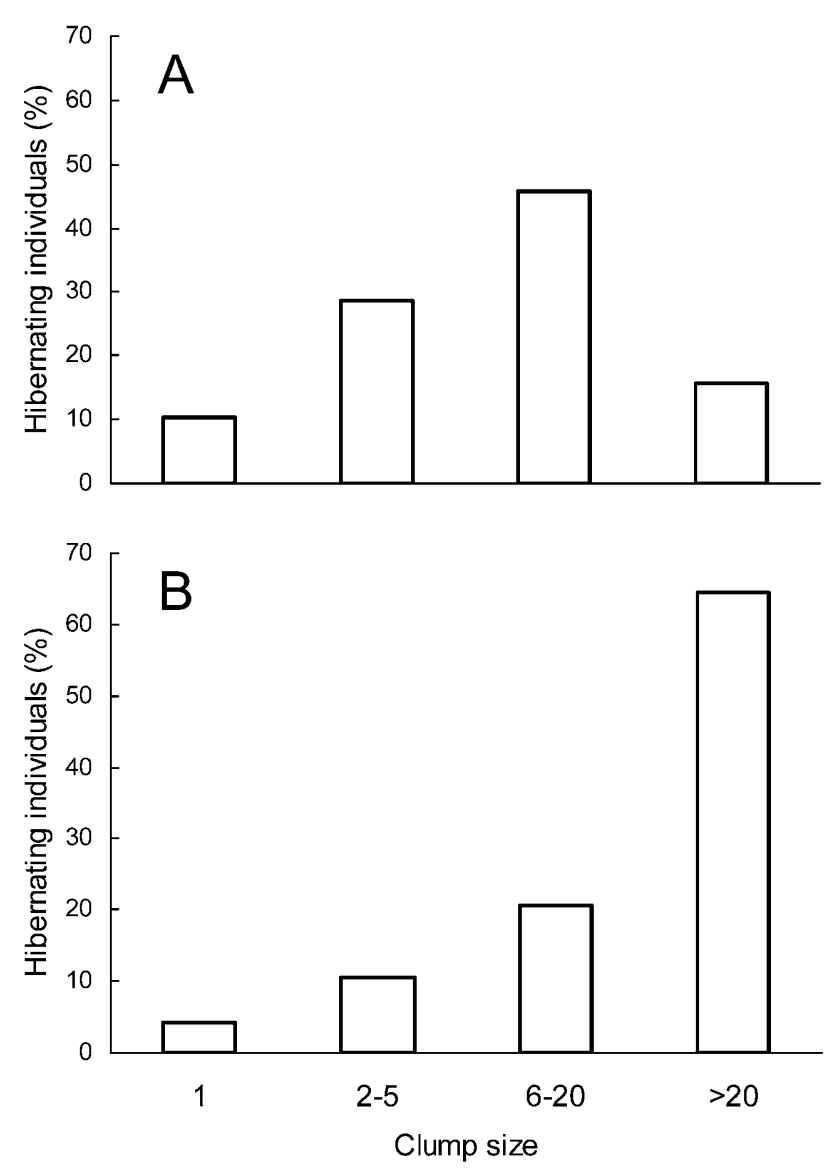

Fig. 5. Percentage of individuals overwintering in clumps of different sizes. Data for Raná, 1978-2003. A - C. septempunctata, B - C. undecimnotata.

carried by the wind to montane hibernation sites and then actively redisperse, and select humid sites for overwintering (Hagen, 1962). Coleomegilla maculata (DeGeer) may also prefer to aggregate in moist places (Benton \& Crump, 1979). By contrast, Harmonia axyridis Pallas forms large aggregations on prominent structures (Obata, 1986; Nalepa et al., 1996). A similar behaviour is observed in C. undecimnotata (Hodek, 1960). Aggregations of these species originate because adults are attracted by environmental stimuli and fly to particular sites. The existence of an intrinsic aggregation tendency, i.e. tendency to join conspecific individuals, is unclear. It might be inferred from the distribution at hibernacula where there is an abundance of apparently similar hibernation sites, like the grass tussocks or stones in this case. Because of the absence of differences between the structures, the clumps may arise due to the mutual attraction of coccinellid adults. This was demonstrated in C. undecimnotata by a preliminary experiment at a hibernation site (Hodek, 1960) and in H. convergens in an olfactory chamber (Copp, 1983).

In this study, the plots where coccinellids overwintered were on southerly exposed slopes of hills, which are warm as a consequence of their exposure to sun and the sparse or absent vegetation. The coccinellids may be attracted to these areas because they are warmer than the surroundings (Iperti, 1966; Honěk, 1989). However, the reason for the aggregated distribution, in areas consisting of apparently similar grass tussocks or stones, which differ little in size, exposure, temperature or humidity, is not obvious. The adults nevertheless aggregated in some tussocks/stones and rejected others. The distribution between tussocks or stones within hibernacula may result from selecting particular structures because of (i) subtle differences of an unidentified nature or (ii) a pioneer conspecific occupying a tussock/stone at random. Once the tussock/stone is occupied further adults prefer to settle there, which finally results in a densely packed group. This behaviour may be seen in late summer. On sunny days, adults temporarily climb up on to the stones and bask in the sun. With the onset of cool weather they return and gather below the stone (A. Honěk, unpubl.). Finally they overwinter in a dense clump in which all individuals are in close contact.

Forming a dense clump requires the precise location of other conspecifics. Studies of foraging, copulation and oviposition behaviour have revealed that coccinellid adults can perceive olfactory (Růžička, 1997; Hamilton et al., 1999; Shonouda, 1999; Schaller \& Nentwig, 2000; Yasuda et al., 2000; Ninkovic et al., 2001) and other chemical stimuli (Hemptinne et al., 1998), and also respond to visual stimuli (Nakamuta, 1984), and that olfactory stimuli provide a cue for aggregation (Copp, 1983; Al Abassi et al., 1998). There are thus several potential mechanisms that overwintering aduts could use to aggregate, but the mechanism is unknown.

The behaviour that brings coccinellids together to form aggregations also results in clumps of different sizes. As there was a surplus of grass tussocks or stones, the typical cluster size was characteristic of the species. In C. septempunctata, the hibernacula were scattered over the whole landscape, and the aggregations were small even when the adults were abundant. This species is apparently reluctant to form large assemblages in which there are several layers of individuals. In contrast, C. undecimnotata prefers hilltop hibernacula and usually overwinters in rock crevices. The assemblages may consist of $10^{3}-10^{4}$ individuals (Hodek, 1960). Its tolerance of contact with conspecifics is apparently greater than that of $C$. septempunctata. Although for C. undecimnotata hibernating in grass tussocks is a marginal option, the size of its aggregations in grass tussocks was significantly greater than those of C. septempunctata, probably because of its intrinsic preferences.

How a clumped distribution contributes to winter survival is not understood. Winter mortality in coccinellids is high and differs between hibernacula (TimofeeffRessovsky, 1940; Lipa et al., 1975; Bazzocchi et al., 2004). Aggregation has been interpreted as a protection against predators and/or parasitoids (see review in Hodek, 1960), but this remains to be tested. By contrast, easy spread of disease is probably the most important disadvantage of clumping (Honěk, 1997) and the potential advantage of clumping must be greater than its risk. In $C$. septempunctata, migration may provide a mechanism 
decreasing risk of spreading disease, particularly in hibernacula at high altitudes where abundance is highest and clumps are largest. In fact, winter mortality and occurrence of diseases was lower in populations originating from hilltops than lowlands (Honěk, 1997). This may be due to selection against weak individuals operating during the autumn migration to hibernation sites. Most individuals develop in lowland agriculture crops (Honěk, $1982,1989)$ and from there fly to hilltop hibernacula, frequently over several kilometres away and several hundred metres higher up. This difficult migration results in the hilltop hibernacula being occupied by larger individuals than lowland hibernacula (Honěk, 1989; Ceryngier, 2000). Small (and/or sick) individuals apparently more frequently stay in lowland hibernacula and generally suffer a high winter mortality (Barron \& Wilson, 1998). This process of "selection" in favour of mainly healthy individuals occupying hilltop hibernacula may also be important in C. undecimnotata.

ACKNOWLEDGEMENTS. We thank A.F.G. Dixon for important comments on the MS and improving the English, $\mathrm{H}$. Uhlírová and L. Kreslová for excellent technical assistance. A.H. and Z.M. were supported by grants no. 0002700603 and 0002700601 of the Czech Ministry of Agriculture and grant no. 522/05/0765 of Grant Agency of the Czech Republic. S.P. was supported by project no. 0021622416 from the Ministry of Education, Youth and Sports of the Czech Republic.

\section{REFERENCES}

Al Abassi S., Birkett M.A., Pettersson J., Pickett J.A. \& Woodcock C.M. 1998: Ladybird beetle odour identified and found to be responsible for attraction between adults. Cell. Mol. Life Sci. 54: 876-879.

BARRON A. \& WILSON K. 1998: Overwintering survival in the seven spot ladybird, Coccinella septempunctata (Coleoptera: Coccinellidae). Eur. J. Entomol. 95: 639-642.

Bazzocchi G.G., Lanzoni A., Accinelli G. \& Burgio G. 2004: Overwintering, phenology and fecundity of Harmonia axyridis in comparison with native coccinellid species in Italy. BioControl 49: 245-260.

Bellows T.S. \& Hassell M.P. 1999: Theories and mechanisms of natural population regulation. In Bellows T.S. \& Fisher T.V. (eds): Handbook of Biological Control. Academic Press, San Diego, pp. 17-44.

Benton A.H. \& CRUMP A.J. 1979: Observations on aggregation and overwintering in the coccinellid beetle Coleomegilla maculata (DeGeer). J. N. Y. Entomol. Soc. 87: 154-159.

Ceryngier P. 2000: Overwintering of Coccinella septempunctata (Coleoptera: Coccinellidae) at different altitudes in the Karkonosze Mts, SW Poland. Eur. J. Entomol. 97: 323-328.

Copp N.H. 1983: Temperature-dependent behaviours and cluster formation by aggregating ladybird beetles. Anim. Behav. 31: 424-430.

Crawley M.J. 2002: Statistical Computing. An Introduction to Data Analysis Using S-Plus. J. Wiley, Chichester, 756 pp.

HAGEN K.S. 1962: Biology and ecology of predaceous Coccinellidae. Annu. Rev. Entomol. 7: 289-326.

Hamilton R.A., Dogan E.B., Schaalje G.B. \& Booth G.M. 1999: Olfactory response of the lady beetle Hippodamia convergens (Coleoptera: Coccinellidae) to prey related odors, including a scanning electron microscopy study of the antennal sensila. Env. Entomol. 28: 812-822.
Hemptinne J.L., Lognay G. \& Dixon A.F.G. 1998: Mate recognition in the two-spot ladybird beetle, Adalia bipunctata: role of chemical and behavioural cues. J. Insect Physiol. 44: $1163-1171$.

HoDEK I. 1960: Hibernation-bionomics in Coccinellidae. Čas. Čs. Spol. Entomol. 57: 1-20.

Hodek I. 1996: Dormancy. In Hodek I. \& Honěk A.: Ecology of Coccinellidae. Kluwer Acad. Publ., Dordrecht, pp. 239-318.

HoNĚK A. 1982: The distribution of overwintered Coccinella septempunctata L. (Col., Coccinellidae) adults in agricultural crops. Z. Angew. Entomol. 94: 311-319.

HoNĚK A. 1989: Overwintering and annual changes of abundance of Coccinella septempunctata in Czechoslovakia (Coleoptera, Coccinellidae). Acta Entomol. Bohemoslov. 86: 179-192.

HonĚK A. 1990: Seasonal changes in flight activity of Coccinella septempunctata L. (Coleoptera, Coccinellidae). Acta Entomol. Bohemoslov. 87: 336-341.

HoNĚK A. 1997: Factors determining winter survival in Coccinella septempunctata (Col.: Coccinellidae). Entomophaga 42: 119-124.

HonĚK A. \& MartinkovÁ Z. 2005: Long term changes in abundance of Coccinella septempunctata (Coleoptera: Coccinellidae) in the Czech Republic. Eur. J. Entomol. 102: 443-448.

HonĚK A. \& REJMÁNEK M. 1982: The communities of adult aphidophagous Coccinellidae (Coleoptera): a multivariate analysis. Acta Oecol. Oecol. Appl. 3: 95-104.

IPERTI G. 1966: Protection of coccinellids against mycosis. In Hodek I. (ed.): Ecology of Aphidophagous Insects. W. Junk, The Hague, pp. 189-190.

Katsoyannos P., Kontodimas D.C. \& Stathas G. 2005: Summer diapause and winter quiescence of Hippodamia (Semiadalia) undecimnotata (Coleoptera: Coccinellidae) in central Greece. Eur. J. Entomol. 102: 453-457.

Lipa J.J., Pruszynski S. \& BARTKowsKi J. 1975: The parasites and survival of the lady bird beetles (Coccinellidae) during winter. Acta Parasitol. Pol. 23: 453-461.

Ludwig J.A. \& Reynolds J.F. 1988: Statistical Ecology. A Primer on Methods and Computing. J. Wiley, New York, 337 pp.

Mooring M.S. \& HartL B.L. 1992: Animal grouping for protection from parasites - selfish herd and encounter-dilution effects. Behaviour 123: 173-193.

NaKamuta K. 1984: Visual orientation of a ladybeetle, Coccinella septempunctata L., (Coleoptera: Coccinellidae), towards its prey. Appl. Entomol. Zool. 19: 82-86.

Nalepa C.A. \& Kidd K.A. \& Ahlstrom K.R. 1996: Biology of Harmonia axyridis (Coleoptera: Coccinellidae) in winter aggregations. Ann. Entomol. Soc. Am. 89: 681-685.

Nedvěd O., Ceryngier P., Hodková M. \& Hodek I. 2001: Flight potential and oxygen uptake during early dormancy in Coccinella septempunctata. Entomol. Exp. Appl. 99: 371-380.

Ninkovic V., Al AbBasi S. \& Pettersson J. 2001: The influence of aphid-induced plant volatiles on ladybird searching behavior. Biol. Contr. 21: 191-195.

Овата S. 1986: Determination of hibernation site in the ladybird beetle Harmonia axyridis Pallas (Coleoptera: Coccinellidae). Kontyu 54: 218-223.

R Development Core Team 2004: R: A language and environment for statistical computing. $R$ Foundation for Statistical Computing Vienna, Austria. Available at http://www.R-project.org.

Ricci C., Ponti L. \& Pires A. 2005: Migratory flight and prediapause feeding of Coccinella septempunctata (Coleoptera) adults in agricultural and mountain ecosystems of Central Italy. Eur. J. Entomol. 102: 531-538. 
RŮžIČKA Z. 1997: Recognition of oviposition-deterring allomones by aphidophagous predators (Neuroptera: Chrysopidae, Coleoptera: Coccinellidae). Eur. J. Entomol. 94: 431-434

Schaller M. \& Nentwig W. 2000: Olfactory orientation of the seven-spot ladybird beetle, Coccinella septempunctata (Coleoptera: Coccinellidae): Attraction of adults to plants and conspecific females. Eur. J. Entomol. 97: 155-159.

SHONOUDA M.L. 1999: Aphid aqueous-extract as a source of host searching kairomones for the aphidophagous predator Coccinella septempunctata L. (Col., Coccinellidae). J. Pest. Sci. 72: $126-128$

Sillen-Tullberg B. \& Leimar O. 1988: The evolution of gregariousness in distastesful insects as a defense against predators. Am. Nat. 132: 723-734.
TAYLOR L.R. 1961: Aggregation, variance and the mean. Nature 189: $732-735$.

Timofeeff-Ressovsky N.V. 1940: Zur Analyse des Polymorphismus bei Adalia bipunctata L. Biol. Zentralbl. 60: 130-137.

Turchin P. \& Kareiva P. 1989: Aggregation in Aphis varians: An effective strategy for reducing predation risk. Ecology 70: 1008-1016.

Yasuda H., TaKagi T. \& Kogi K. 2000: Effects of conspecific and heterospecific larval tracks on the oviposition behaviour of the predatory ladybird, Harmonia axyridis (Coleoptera: Coccinellidae). Eur. J. Entomol. 97: 551-553.

Received May 11, 2006; revised and accepted September 7, 2006 